Oxalis corniculata $\mathrm{L}$., with its yellow flowers, was likewise seen, but not in any quantity.

An interesting plant-Chenopodium tomentosum Th.grows abundantly on Tristan as well as on Inacessible Island; it is known as the tea plant, and the leaves, which are strongly scented, are used for making a decoction which is drunk with milk and sugar.

In the gully above the settlement, shrubs of Phylica arborea commence at an elevation of about $400 \mathrm{ft}$. No trees are found in this locality, having all been cut down at different times for fire-wood, but on other parts of the island there is abundance of wood. The diameter of the trunks of the trees on the upper plateau, it is said, reach to $\mathrm{r} 8 \mathrm{in}$. On some fresh-water ponds close to the sea was a quantity of confervæ, but no chara was seen, a species of Isolepis also grew on the edges of these ponds which was not seen on the other two islands. A few willow bushes grew in a sheltered situation in a ditch near the cottages, and seemed to be thriving. Growing round the island is a belt of Macrocystis pyrifera Ag., a gigantic sea-weed, abounding in the southern temperate zone, and stretching up from thence along the Pacific to the Arctic regions. It occurs in immense lengths, single plants of from tco to $200 \mathrm{ft}$. being common, and it is said that they are sometimes seen from 700 to $x, 000 \mathrm{ft}$. in length, forming cable-like masses nearly as thick as a man's body, and having the appearance of huge buoys.

The surf on the rocky coast of Tristan is so heavy that the more delicate sea-weeds stand no chance, but are dashed and torn into numerous pieces.

The temperature of the fresh-water ponds at the sealevel gave a result of $54^{\circ} \mathrm{F}$. while the water of the streams running down the cliffs stood at $50^{\circ}$, the difference being due evidently to the influence of the snow-water from above.

\section{FUNERAL OF THE LATE DR. LIVINGSTONE}

N Saturday last the remains of David Livingstone, which left Central Africa now nearly a year ago, were interred in Westminster Abbey, in presence of a multitude such as was probably never collected therein on any similar occasion. The funeral procession, which started from the Geographical Society's Rooms, Savile Row, was of great length, though of the plainest description possible under the circumstances; we have not learned whether this was in accordance with the wishes of the late traveller's relatives, or whether it arose from scarcity of funds. Every mark of respect was shown to the procession along its route, and at several advantageous points considerable crowds had collected to witness the last journey of the great explorer.

Men of all ranks and of all pursuits in life formed part of the procession, and stood around the grave during the service in the Abbey. The patriarchal Dr. Moffat, Livingstone's father-in-law, and the traveller's two sons, Thomas and Oswell Livingstone, Mr. James Vavasseur, Sir F. Steele, Dr. Kirk, Mr. W. F. Webb, the Rev. Horace Waller, Mr. H. M. Stanley, Mr. E. Young, Sir W. Fergusson, the Duke of Sutherland, Sir Bartle Frere (President of the Royal Geographical Society), Sir H. C. Rawlinson, Vice-Admiral Baron de la Ronciere le Noury (President of the French Geographical Society), Dr. Hooker (President of the Royal Society), Mr. C. R. Markham, Mr. R. H. Major, Mr. H. W. Bates, Dr. Houghton, Mr. J. Young of Kelly, are the names of some of those who followed the body to the grave; there were besides, deputations from Edinburgh, Glasgow, and other places, and the carriages of Her Majesty the Queen, the Prince of Wales, and of many other noble and distinguished persons formed part of the procession. Among those who were waiting inside the Abbey were men of every shade of thought, political and religious, men distinguished in every walk of life, deputations from many religious bodies, from the establishment outwards, and representatives of various scientific Societies. The bearing of the crowds both outside and inside the Abbey showed that they were brought together from genuine admiration and sincere respect for the memory of the simple-minded hero.

We think the character of the assemblage which gathered to do honour to Livingstone's remains is one proof that he has done a work calculated to call forth the admiration and gratitude of those whose suffrages constitute fame of the highest and most enduring kind. If to conceive a great and noble purpose and to carry it out even unto death, with indomitable energy, determination, and the greatest skill, in the face of every possible discouragement, discomfort, and obstacle, be a mark of greatness, his contemporaries have certainly made no mistake in raising David Livingstone to the lofty pedestal which he at present occupies. $\mathrm{He}$ has probably added more largely to the sum of exact geographical knowledge than any other explorer has hitherto done. As Dean Stanley eloquently said in his funeral sermon on Sunday afternoon :- "By his indomitable resolution we have now revealed to us, for the first time, that vast tract of Central Africa which, to the contemplation of the geographer, has been literally transformed from a howling wilderness into the glory of Lebanon. The blank of unexplored regions which in every earlier map formed the heart of Africa is now disclosed to us adorned with those magnificent forests, that chain of lakes 'glittering'- to use the native expression-'like stars in the desert ;" those falls more splendid, we are told, even than Niagara, which no eye of civilised man had ever before beheld. And to his untiring exertions, continued down to the very last efforts of exhausted nature, we owe the gradual limitation of the basin within wbich must at last be found those hidden fountains that have lured on traveller after traveller, and have hitherto baffled them all."

A deputation of gentlemen interested in the family of the late Dr. Livingstone waited on Monday upon the Chancellor of the Exchequer and the Secretary of State for Foreign Affairs, for the purpose of representing to $\mathrm{Her}^{-}$ Majesty's Government the very general anxiety that was felt throughout the United Kingdom that some substantial recognition, in the shape of an adequate provision for his family, should be made of the services of the great traveller. A requisition to the Prime Minister, asking him to confer a pension on the family of Dr. Livingstone, was on Monday night circulated among members of Parliament at the House of Commons. A large number of signatures has already been attached by gentlemen on both sides.

About three years ago, Her Majesty, at the recommendation of $\mathrm{Mr}$. Gladstone, conferred a pension of $300 l$. a year upon Dr. Livingstone, who, however, it is sad to think, never knew that his services had been so recognised by the Government. Upon the death of Livingstone the pension ceased, but it was deemed by $\mathrm{Mr}$. Gladstone a matter of sheer merit, due to the great explorer, to confer some pecuniary benefit upon his children, and the figures on the civil list were thereupon reduced from $300 l$. to $200 l$., which is actually the amount that will henceforth be paid by the Government to those he has left behind him. Though Dr. Livingstone made a large sum of money out of the first book he published, still he disbursed more than half that amount in his promotion of the exploration of the Zambesi.

Livingstone's devotion to the cause of science and of philanthropy has thus been the means of leaving his family very inadequately provided for; but as he has added so greatly to the glory of his native land, and as he spent his life in the service of civilisation, we feel confident that those for whom he was therefore unable to provide will be well cared for.

From a letter in yesterday's Times we see that the Diary kept by Jacob Wainwright for nine months after Livingstone's death will shortly be published. 